\title{
IMPLEMENTASI UPACARA ADAT NYANGKU DI SITUS SITU LENGKONG PANJALU
}

\author{
Krisna Sujaya ${ }^{1}$ \\ Dosen Universitas Siliwangi \\ Jl. Siliwangi No. 24 Kota Tasikmalaya 46115 Jawa Barat
}

\begin{abstract}
ABSTRAK
Masyarakat di wilayah Panjalu, memiliki upacara adat setempat yang menjadi identitas masyarakat panjalu itu sendiri. Salah satu upacara adat yang dijaga dan dilestarikan oleh masyarakat Panjalu yaitu Upacara Adat Nyangku. Upacara Adat Nyangku adalah sebuah instrumen yang dipakai oleh nenek moyang masyarakat panjalu dalam mensiarkan agama islam. Penelitian ini menggunakan metode penelitian deskriptif kualitatif. Barang-barang yang di bersihkan ketika prosesi upacara adat nyangku yaitu: 1) Pedang, sebagai senjata yang digunkan sebagai sarana untuk penjagaan diri ketika menyebarkan agama islam, 2) Cis, merupakan tombak sebagai senjata yang digunkan sebagai sarana untuk penjagaan diri ketika menyebarkan agama islam, 3) Keris komando, bekas senjata yang digunakan raja panjalu sebagai alat komando dalam pemerintahan di kerajaan Panjalu, 4) Keris, merupakan pegangan atau koleksi para bupati panjalu terdahulu, 5) Pancaworo, merupakan alat yang digunakan sebagai senjata perang zaman dahulu, 6) Bangreng, merupakan alat yang digunakan sebagai senjata perang zaman dahulu, 7) Gong kecil, merupakan alat yang digunakan untuk mengumpulkan rakyat pada zaman dahulu.Selanjutnya di hari yang ditentukan, ketika Upacara Adat Nyangku siap untuk dilaksanakan, ada syarat khusus yang harus di patuhi yaitu 1) Cara Berpakaian, 2) Tata Cara Kirab Benda-benda peninggalan Kerajaan Panjalu. Apabila di analisis lebih lanjut, pada dasarnya tidak semua benda peninggalan di bersihkan ketika prosesi Upacara Adat Nyangku. Benda-benda peninggalan yang lain biasanya dibersihkan besok harinya. Hal yang demikian tersebut bertujuan agar prosesi Upacara Adat Nyangku berjalan efektif tanpa memakan waktu yang lama. Benda peningalan yang dibersihkan ketika prosesi Upacara Adat Nyangku hanya benda peninggalan asli Kerajaan Panjalu saja yaitu: 1) Pedang, 2) Keris Komando
\end{abstract}

\section{Kata Kunci: Upacara Adat, Nyangku, Upacara Adat Nyangku}

\begin{abstract}
Communities in the Panjalu region have local traditional ceremonies which become the identity of the panjalu community itself. One of the traditional ceremonies which is guarded and preserved by the Panjalu community is the Nyangku Traditional Ceremony. Nyangku Traditional Ceremony is an instrument used by the ancestors of the panjalu community in promoting Islam. This study uses a qualitative descriptive research method. The items that were cleaned during the procession of the Nyangku traditional ceremony, namely: 1) The sword, as a weapon used as a means of self-defense when spreading Islam, 2) Cis, was a spear as a weapon used as a means of self-defense when spreading Islam, 3) Keris command, former weapons used by king Panjalu as a command tool in the government in the kingdom of Panjalu, 4) Keris, is the handle or collection of the previous long-time regents, 5) Pancaworo, a tool used as an ancient weapon of war, 6) Bangreng, a tool used as an ancient war weapon, 7) Small Gong, is a tool used to gather people in ancient times. Furthermore, on the appointed day, when the Nyangku Traditional Ceremony is ready to be carried out, there are special conditions that must be obeyed, namely 1) How to dress, 2) Procedure for Kirab Heritage objects of Panjalu Kingdom. If further analyzed, basically not all relics are cleared during the procession of my Nyangku Traditional Ceremony. Other relics are usually cleaned tomorrow. This is intended to make the Nyangku Traditional Ceremony process effective without taking a long time. Restored objects that are cleaned during the procession of the Nyangku Traditional Ceremony are only the original relics of the Panjalu Kingdom, namely: 1) Swords, 2) Keris Komando
\end{abstract}

\section{Keywords: Traditional Ceremony, Nyangku, My Traditional Ceremony}

\footnotetext{
${ }^{1}$ Penulis Koresponden

E-mail address: jurnalartefaksejarah@gmail.com doi: http://dx.doi.org/10.25157/ja.v5i2.1935
}

Copyright@2018 Jurnal Artefak e-ISSN: 2580-0027

Halaman | 49 


\section{PENDAHULUAN}

Kebudayaan adalah suatu hal yang berperan penting dalam keberlangsungan hidup masyarakat. Oleh karena itu, kebudayaan sangat mempengaruhi sistem kehidupan masyarakat. orisinalitas kebudayaan tidak dapat prediksi tanpa adanya sebuah studi yang membahas kebudayaan tersebut, hal tersebut disebabkan kebudayaan merupakan konsep yang abstrak dan bebas. Abstrak karena bentuknya yang tidak tampak karena mengikuti pola kehidupan masyarakatnya dan bebas dapat diartikan karena kebudayaan tidak terikat dengan hal-hal tertentu, akan tetapi kebudayaan dapat berubah menyesuaikan dengan perubahan yang ada di dalam kehidupan masyarakat.

Menurut J. J. Honigman dalam Koentjaraningrat (2000: 187) terdapat tiga wujud gejala kebudayaan yaitu ide (ideas), aktivitas (activies), dan artefak (artifacts).

1. Ide (ideas) merupakan satu perwujudan dari sebuah pemikiran dan gagasan dari seorang individu yang terdiri dari segenap peraturan yang telah disepakati dalam masyarakat.

2. Aktivitas (activies) merupakan kegiatan yang dilakukan oleh individu yang dapat terbentuk dari interaksi antar individu.

3. Artefak (artifacts) atau kebudayaan fisik merupakan hasil dari karya, ide, dan gagasan manusia.

Kebudayaan merupakan suatu bentuk hasil cipta, karya dan karsa dari manusia yang membentuk sebuah peradaban. Manusia yang membentuk sebuah peradaban sudah dapat dipastikan akan memiliki sebuah bentuk kebudayaan. Setiap masyarakat pasti memiliki kebudayaan, baik kebudayaan fisik maupun non fisik.. Kebudayaan memiliki makna yang sangat urgen di dalam kehidupan masyarakat yang tidak bisa ditinggalkan begitu saja, bahkan ada sebuah tanggung jawab bagi masyarakat untuk menjaga dan melestarikan kebudayaan tersebut.

Tradisi dalam kebudayaan adalah sebuah kebiasaan yang tersusun secara sistematik dan diwariskan secara turun temurun. prubahan zaman dan pengaruh teknologi dan modernisasi akan sangat berpengaruh terhadap sebuah tradisi yang menyebabkan pergeseran dan perubahan pemaknaan serta fungsinya. Kebudayaan adalah suatu hal yang abstrak dan bebas tanpa terikat dengan suatu hal atau bentuk-bentuk tertentu. Akulturasi budaya memiliki peranan penting dalam perkembangan kebudayaan. Ada masa ketika sebuah kebudayaan terintegrasi oleh kebudayaan lain dan merubah bentuk kebudayaan tersebut baik sebagian ataupun menyeluruh.

Upacara adat yang merupakan suatu bentuk kebudayaan dari masyarakat sebelumnya atau sering disebut dengan para leluhur dari suatu masyarakat, mempunyai arti yang penting di dalam kehidupan masyarakat dan telah menjadi suatu bentuk kebiasaan yang harus dilaksanakan. Upacara adat mengandung makna simbolik, nilai-nilai etika, moral, dan sosial yang mencerminkan adanya suatu pengaruh dari sistem religi atau kepercayaaan. Pengaruh tersebut merupakan salah satu unsur universal dari kebudayaan (Winataputra, 2007: $3)$.

Upacara adat di Indonesia dijadikan sebuah identitas dari suatu masyarakat karena merupakan prodauk dari kebudayaan yang sudah dihasilkan oleh masyarakat setempat sejak jaman nenek moyang. Upacara adat juga dapat diartikan sebagai sebuah instrumen sebagai alat pemersatu di dalam masyarakat, hal itu dikarenakan pada saat prosesi upacara adat masyarakat dengan konsisten menjunjung tinggi jiwa kebersamaan tanpa ada perbedaan.

Masyarakat di wilayah Panjalu, memiliki upacara adat setempat yang menjadi identitas masyarakat panjalu itu sendiri. Upacara adat tersebut senantiasa dijaga dan dilestarikan di era perkembangan teknologi dan tingkat modernisasi yang tinggi. Salah satu upacara adat yang dijaga dan dilestarikan oleh masyarakat Panjalu yaitu Upacara Adat Nyangku. Upacara Adat Nyangku adalah sebuah instrumen yang dipakai oleh nenek moyang masyarakat panjalu dalam mensiarkan agama islam. Akan tetapi, seiring perkembangan zaman dan proses akulturasi budaya yang terus menerus Upacara Adat Nyangku sudah mengalami perubahan dalam pemaknaan dan fungsi strategisnya.

Konsep Pelestarian adalah sebuah strategi untuk menjaga dan mempertahankan kebudayaan lokal setempatyang diwariskan secara turun temurun, pelestarian berfungsi supaya kebudayaan lokal yang diwariskan tersebut dapat bertahan dan berkembang sehingga dapat di turunkan kembali kepada generasi berikutnya agar dapat di laksanakan dala kehidupan masyarakat pada generasi selanjutnya. Upacara Adat Nyangku merupakan 
sebuah ritual adat yang dilakukan untuk memandikan benda-benda peninggalan kerajaan Panjalu. Secara historis Upacara Adat Nyangku merupakan suatu acara ritual yang dianggap agung (besar), karena memiliki makna dan fungsi tertentu. makna dan fungsi dari Upacara Adat Nyangku yaitu sebagai sarana penyebaran Agama Islam dan pemberssihan/penyucian benda-benda peninggalan kerajaan.

Makna dan fungsi dari implementasi Upacara Adat Nyangku merupakan sebuah instrumen penyebaran Agama Islam, hal tersebut dilaksanakan karena bila ditinjau dari presfektif historis konon dulu kerajaan Panjalu ketika di pimpin oleh seorang raja yang bernama Borosngora memiliki cita-cita untuk mengislamkan masyarakat kerajaan Panjaludengan alasan dahulu masyarakat kerajaan Panjalu masih mayoritas menganut agama hindu/budha, maka raja memiliki sebuah terobosan agar islami tersebut dapat diterima tanpa menimbulkan sebuah polemik maka raja Borosngora berinisiatif menginternalisasikan nilai-nilai keislaman dengan kebudayaan lokal yaitu dengan strategi internalisasi nilai-nilai yang dimaksud dengan Upacara Adat Nyangku. Seiring dengan perkembangan zaman dan meningkatnya arus teknologi dan modernisasi Upacara Adat Nyangku dilaksanakan hanya untuk membersihkan benda-benda peninggalan Kerajaan Panjalu, karena pada zaman sekarang agama islam sudah menyebar di wilayah panjalu dan mayoritas masyarakatnya beragama islam.

\section{METODE PENELITIAN}

Penelitian ini menggunakan metode penelitian deskriptif kualitatif. Menurut Kirk dan Miller, penelitian kualitatif merupakan tradisi tertentu dalam ilmu pengetahuan sosial secara fundamental bergantung pada pengamatan manusia dan kawasannya sendiri serta berhubungan dengan orang-orang tersebut dalam bahasanya dan peristilahannya (Moleong, 2005:3). Teknik pengumpulan data pada penelitian ini dilakukan dengan menggunakan teknik observasi, wawancara dan dokumentasi. Penelitian ini menggunakan teknik triangulasi data untuk menentukan validitas data.

\section{HASIL PENELITIAN DAN PEMBAHASAN}

Sebuah kebudayaan bisa berubah dan menyesuaikan dengan karakteristik dari masyarakat yang melestarikannya. Kebudayaan selalu berhubungan dengan masyarakat dan sebaliknya masyarakat yang membentuk sebuah peradaban sudah hampir dipastikan menciptakan sebuah produk kebudayaan. Untuk itu, apabila terjadi perubahan terhadap kultur sosial kemasyarakatan maka akan secara otomatis kebudayaan tersebuta juga akan ikut berubah. Perubahan tersebut secara universal diakibatkan oleh berbagai pengaruh dari arus modernisasi dan globalisasi yang sesuai dengan dinamika perkembangan zaman. Secara otomatis maka proses akulturasi budaya terhadap budaya lokal pun semakin memprihatinkan.

Kecamatan panjalu Panjalu merupakan salah satu wilayah kecamatan yang terletak di Kabupaten Ciamis, Provinsi Jawa Barat. Kecamatan Panjalu memiliki peranan sangat penting sebagai sentra wisata budaya dan religi. Kecamatan Panjalu terletak kurang lebih 35 km arah utara Kabupaten Ciamis. Sebelah utara berbatasan dengan wilayah Kabupaten Majalengka dan Kabupaten Kuningan. Letak geografis wilayah Panjalu berupa perbukitan yang subur, di kaki gunung Sawal dengan ketinggian sekitar 700 dpl. Kecamatan Panjalu terdiri dari sekitar 8 Desa yaitu: Desa Panjalu, Desa Kertamandala, Desa Mandalare, Desa Ciomas, Desa Sandingtaman, Desa Maparah, Desa Bahara, Desa Hujungtiwu.

Kehidupan budaya masyarakat Panjalu sangat baik dikarenakan masih secara konsisten memelihara dan melestarikan kearifan lokal setempat, salah satu bentuk kearipan lokal yang masih dijaga dan dilestarikan serta dikembangkan yaitu Upacara Adat Nyangku. Upacara adat ini diwariskan secara turun temurun sejak akhir abad ke-7 sampai sekarang.

Makna dari Upacara Adat Nyangku merupakan instrumen pembersihan diri dari segala hal yang dilarang oleh Agama Islam. Upacara Adat Nyangku juga berfungsi untuk memperingati Maulid Nabi besar Muhammad SAW, serta sebagai kegiatan untuk mempererat silaturahmi dan jiwa kebersamaan masyarakat Kecamatan Panjalu. implementasi Upacara Adat Nyangku di diselenggarakan oleh tokoh adat Panjalu serta Pemerintah daerah setempat. Sementara dari segi kelembagaan Upacara Adat 
Nyangku diselenggarakan di bawah naungan Yayasan Borosngora.

Dalam prosesi Upacara Adat Nyangku turut dibersihkan benda-benda peninggalan kerajaan panjalu yang tersimpan di musium bumi alit, barang-barang yang di bersihkan ketika prosesi upacara adat nyangku yaitu:

1. Pedang, sebagai senjata yang digunkan sebagai sarana untuk penjagaan diri ketika menyebarkan agama islam.

2. Cis, merupakan tombak sebagai senjata yang digunkan sebagai sarana untuk penjagaan diri ketika menyebarkan agama islam.

3. Keris komando, bekas senjata yang digunakan raja panjalu sebagai alat komando dalam pemerintahan di kerajaan Panjalu.

4. Keris, merupakan pegangan atau koleksi para bupati panjalu terdahulu.

5. Pancaworo, merupakan alat yang digunakan sebagai senjata perang zaman dahulu.

6. Bangreng, merupakan alat yang digunakan sebagai senjata perang zaman dahulu.

7. Gong kecil, merupakan alat yang digunakan untuk mengumpulkan rakyat pada zaman dahulu.

Benda-benda yang di bersihkan pada upacara adat nyangku sebenarnya tidak semuanya peninggalan zaman kerajaan Panjalu, akan tetapi merupakan barang-barang peninggalan yang sengaja di titipkan di musium bumi alit. Masyarakat yang menitipkan barang peninggalan leluhur tersebut berasal dari masyarakat panjalu sendiri dan masyarakat luar panjalu yang mempercayakan benda peninggalan tersebut ke musium bumi alit. Barang-barang peninggalan yang di titipkan oleh masyarakat di bumi alit adalah barangbarang milik pribadi yang diwariskan turuntemurun dari keluarganya. Alasan paling besar dari dititipkannya benda-benda peninggalan yang wariskan secara turun temurun tersebut diakibatkan banyak terjadi kejadian yang tidak bisa di jangkau oleh logika, oleh karena itu masyarakat lebih percaya untuk menitipksn barang-barang peninggalan keluarganya di musium bumi alit.

Persiapan implementasi kegiatan Upacara Adat Nyangku pada dasarnya diawali oleh pengajian rutin yang diselenggarakan di musium bumi alit. Pengajian itu diselenggarakan dalam rangka memperingati kelahiran Nabi Muhammad SAW yang dihadiri oleh para tokoh-tokoh adat di Kecamatan Panjalu serta masyarakat Kecamatan panjalu, dan banyak pula masyarakat dari luar daerah yang sengaja datang untuk mengikuti pengajian tersebut.

Selanjutnya di hari yang ditentukan, ketika Upacara Adat Nyangku siap untu dilaksanakan, ada syarat khusus yang harus di patuhi yaitu

1. Cara Berpakaian

Keturunan dan para tokoh adat Panjalu yang terlibat di wajibkan menggunakan pakaian adat berupa ikat kepala dan baju pangsi baik yang berwarna hitam ataupun putih. Hal tersebut tidak diwajibkan kepada pengunjung yang mengikuti prosesi Upacara Adat Nyangku.

2. Tata Cara Kirab Benda-benda peninggalan Kerajaan Panjalu

Keturunan-keturunan Raja kerajaan Panjalu di susun rapi dan diharuskan untuk berjalan rapi menuju Museum Bumi Alit, untuk mempersiapkan benda-benda peninggalan yang akan dikirap.

Apabila di analisis lebih lanjut, pada dasarnya tidak semua benda peninggalan di bersihkan ketika prosesi Upacara Adat Nyangku. Benda-benda peninggalan yang lain biasanya dibersihkan besok harinya. Hal yang demikian tersebut bertujuan agar prosesi Upacara Adat Nyangku berjalan efektif tanpa memakan waktu yang lama. Benda peningalan yang dibersihkan ketika prosesi Upacara Adat Nyangku hanya benda peninggalan asli Kerajaan Panjalu saja yaitu:

1. Pedang

Konon katanya merupakan pedang hadiah dari Saidina Ali RA kepada prabu Borosngora

2. Keris Komando

Ketika jaman dulu Panjalu masih berbentuk kerajaan dijadikan lambang kerajaan dalam memerintah

Rombongan yang membawa bendabenda peninggalan kerajaan Panjalu di kirab oleh para peserta kirab sambil diiringi musikmusik tradisional sunda buhun dan kemudian benda-benda peninggalan tersebut dikirab menuju situ gede Panjalu guna di laksanakan ritul-ritual khusus yang dilaksanakan oleh para pemangku adat dan masyarakat. Setelah kegiatan tersebut selesai benda-benda peninggalan kerajaan Panjalu tersebut kembali di kirab ke tempat pembersihan benda 
peninggalan yang sudah ditentukan, yaitu di alun-alun Kecamatan Panjalu.

Sarana utama pembersihan benda-benda peninggalan kerajaan tersebut yaitu:

1. Air

Air yang dipakai untuk membersihkan benda-benda peninggalan berdasarkan hasil observasi diambil dari 9 (sembilan) sumber mata air yang dikeramatkan oleh masyarakat Kecamatan Panjalu. Sumber mata air tersebut berasal dari sumber mata air gunung bitung, mata air gunung sawal, mata air cipanjalu, mata air situ lengkong, mata air kapunduhan, mata air ciater, mata air gunung tilu, mata air cilimus, dan mata air ciomas. Air tersebut di bawa menggunakan "kele" yaitu sebuah tempat yang dibuat dari bambu dan dilubangi dibagian atasnya.

\section{Jeruk Nipis}

Jeruk Nipis dipakai untuk menghilangkan karat dari benda-benda peninggalan kerajaan Panjalu yang pada dasarnya terbuat dari bahan besi tempa yang dikarenakan termakan usia pasti menimbulkan karat yang cukup tebal.

Hal unik yang terjadi ketika prosesi pembersihan benda-benda peninggalan kerajaan Panjalu yaitu masyarakat yang berpartisipasi dalam prosesi Upacara Adat Nyangku berebut untuk meminta air yang dipakai untuk membersihkan benda-benda peninggalan kerajaan Panjalu, karena mereka meyakini bahwa air tersebut dapat membawa manfaat bagi orang yang memanfaatkannya. Terlepas dari pada itu, dengan tidak adanya konflik antar peserta yang memperebutkan air tersebut menunjukan bahwa rasa kebersamaan dari masyarakat peserta Upacara Adat Nyangku selalu di junjung tinggi dan jiwa toleransi semakin terpupuk di dalam sanubari masyarakat yang mengikuti prosesi Upacara Adat Nyangku.

Dari prespektif penyelenggaraan dari sisi keamanan, penyelenggara membuat benteng hidup di sekeliling lokasi utama pembersihan benda-benda peninggalan kerajaan Panjalu. Hal tersebut di lakukan agar prosesi pembersihan benda-benda peninggalan kerajaan Panjalu berjalan dengan lancar. Penyelenggara pada dasarnya sudah mencoba mengantisipasi hal-hal yang mengganggu prosesi pembersihan bendabenda peninggalan kerajaan Panjalu seperti meminimalisir warga masyarakat yang memaksa ingin mendapatkan air yang digunakan sebagai sarana pembersih.

Setelah rangkaian prosesi pembersihan benda-benda peninggalan kerajaan Panjalu telah selesai, selanjutnya, benda-benda peninggalan kerajaan Panjalu di hangatkan diatas bara api yang sudah disiapkan, tujuan dari hal tersebut yaitu untuk mempercepat proses pengeringan dari benda-benda peninggalan kerajaan Panjalu setelah dibersihkan. Setelah kering, bendabenda peninggalan kerajaan Panjalu lalu dibungkus kembali dengan kain putih dikembalikan lagi ke Museum Bumi

Peran masyarakat dalam prosesi Upacara Adat Nyangku sangat besar. Upacara Adat Nyangku sampai saat ini terus dilestarikan tidak lain karena masyarakatpun ikut menjaga dan berpartisipasi dalam Upacara Adat Nyangku. Itu mengindikasikan bahwa masyarakat, khusunya masyarakat Kecamatan Panjalu senantiasa menjaga dan melestarikan nilai-nilai kearifan lokal yang di wariskan oleh generasigenerasi terdahulu.

\section{PENUTUP}

\section{Simpulan}

Barang-barang yang di bersihkan ketika prosesi upacara adat nyangku yaitu: 1) Pedang, sebagai senjata yang digunkan sebagai sarana untuk penjagaan diri ketika menyebarkan agama islam, 2) Cis, merupakan tombak sebagai senjata yang digunkan sebagai sarana untuk penjagaan diri ketika menyebarkan agama islam, 3) Keris komando, bekas senjata yang digunakan raja panjalu sebagai alat komando dalam pemerintahan di kerajaan Panjalu, 4) Keris, merupakan pegangan atau koleksi para bupati panjalu terdahulu, 5) Pancaworo, merupakan alat yang digunakan sebagai senjata perang zaman dahulu, 6) Bangreng, merupakan alat yang digunakan sebagai senjata perang zaman dahulu, 7) Gong kecil, merupakan alat yang digunakan untuk mengumpulkan rakyat pada zaman dahulu. Selanjutnya di hari yang ditentukan, ketika Upacara Adat Nyangku siap untuk dilaksanakan, ada syarat khusus yang harus di patuhi yaitu 1) Cara Berpakaian, 2) Tata Cara Kirab Benda-benda peninggalan Kerajaan Panjalu. Apabila di analisis lebih lanjut, pada dasarnya tidak semua benda peninggalan di bersihkan ketika prosesi Upacara Adat Nyangku. Benda-benda peninggalan yang lain biasanya dibersihkan besok harinya. Hal yang demikian tersebut bertujuan agar prosesi Upacara Adat Nyangku berjalan efektif tanpa memakan waktu yang lama. Benda peningalan 
yang dibersihkan ketika prosesi Upacara Adat Nyangku hanya benda peninggalan asli Kerajaan Panjalu saja yaitu: 1) Pedang, 2) Keris Komando

\section{Saran}

Pertama, pemerintah sudah selayaknya leih memperhatikan pelestarian nilai-nilai kearifan lokal khususnya upacara adat Nyangku. Kedua, masyarakat senantiasa harus melestarikan nilai-nilai budaya dan memurnikan kembali Upacara Adat Nyangku sesuai dengan syariat islam sebagai mana tujuan utama Upacara Adat Nyangku itu sendiri.

\section{DAFTAR PUSTAKA}

Koentjaraningrat. 2000. Pengantar Ilmu Sosiologi. Jakarta: Rineka Cipta.

Maleong, Lexy J. 2005. Metodologi Penelitian Kualitatif. Bandung: Remaja Rosdakarya

Rostiati, A, dkk. (1995). Fungsi Upacara Tradisional Bagi Masyarakat Pendukungnya. Bandung: Depdikbud, Dirjen Sejarah dan Nilai Tradisional/Proyek Penelitian, Pengkajian, dan Pembinaan Nilai-nilai Budaya Jawa Barat

Setiawan, Guntur. 2004. Impelemtasi dalam Birokrasi Pembangunan. Jakarta: Balai Pustaka

Udin S. Winaputra. M. A. dkk. . 2007. Materi dan Pembelajaran IPS.Jakarta: Universal Terbuka.

Usman, Nurdin. 2002. Konteks Implementasi Berbasis Kurikulum. Jakarta: Grasindo 